\title{
Essential Subtleties on the Silver Sea
}




\section{General Editor}

John M. Janzen

Founding Editor

Charles Leslie

Editorial Board

Don Bates, M.D.,

McGill University

Frederick L. Dunn, M.D., University of California, San Francisco

Kris Heggenhougen,

Harvard University

Brigitte Jordan,

Michigan State University

Shirley Lindenbaum,

The Graduate School and University Center of the

City University of New York

Patricia L. Rosenfield, The Carnegie Corporation of New York

Paul U. Unschuld,

University of Munich

Francis Zimmermann,

Centre National de la Recherche Scientifique, Paris

For a complete list of titles in this series, please contact the

Sales Department

University of California Press

2120 Berkeley Way

Berkeley, CA 94720 
The Chinese Medical Classics

\section{Essential Subtleties on the Silver Sea}

The Yin-hai jing-wei: A Chinese Classic on Ophthalmology

TRANSLATED AND ANNOTATED BY

Jürgen Kovacs and Paul U. Unschuld 
The publisher gratefully acknowledges the generous contribution toward the publication of this book provided by the Chiang Ching-kuo Foundation for International Scholarly Exchange.

\author{
University of California Press \\ Berkeley and Los Angeles, California \\ University of California Press \\ London, England
}

Copyright (C) $199^{8}$ by The Regents of the University of California

Library of Congress Cataloging-in-Publication Data

Sun, Ssu-miao, $5^{81-682}$

[Yin hai ching wei. English]

Essential subtleties on the silver sea : the Yin-hai jing-wei : a

Chinese classic on ophthalmology / translated and annotated by Jürgen Kovacs and Paul U. Unschuld.

p. cm. - (Comparative studies of health systems and medical care; no. $3^{8}$ )

Includes bibliographical references and index.

At head of title: Chinese medical classics.

ISBN 0-520-08058-o (cloth : alk. paper)

I. Eye-Diseases-Early works to 1800 . 2. Medicine, Chinese-

Early works to 1800 . I. Kovacs, Jürgen. II. Unschuld, Paul U.

(Paul Ulrich), 1943- . III. Title. IV. Title: Yin-hai jing-wei.

V. Title: Chinese medical classics. VI. Series.

[DNLM: r. Eye Diseases. 2. Medicine, Chinese Traditional. WI $\mathrm{CO}_{437} \mathrm{~S}$ no. $\left.3^{8}{ }_{1998} / \mathrm{WZ} 290 \mathrm{~S}_{957 y c} 1998 \mathrm{a}\right]$

$\mathrm{RE}_{4} 8 . \mathrm{S}^{8} \mathrm{1}_{3}{ }_{1998}$

$617.7-\mathrm{dc} 21$

DNLM/DLC

for Library of Congress

$97-138$

CIP

Printed in the United States of America

122344566789

The paper used in this publication meets the minimum requirements of American National Standard for Information Sciences-Permanence of Paper for Printed Library Materials, ANSI Z39.48-1984 